\title{
Ethics of prayer and work in 1 and 2 Thessalonians
}

Author:
Jean-Claude Loba-Mkole ${ }^{1}$
Affiliation:
${ }^{1}$ Department of New
Testament Studies,
University of Pretoria,
South Africa
Note:
Dr Jean-Claude Loba-
Mkole (OP, STD, PhD) is
a research associate of
Professor Gert Steyn and
Professor Extraordinary
in the Department of the
New Testament Studies,
University of Pretoria. He is
grateful for the research grant
he received from Professor
Gert Steyn to complete
this article during a visit at
the Department of New
Testament Studies, University
of Pretoria, South Africa
(29 July-29 September 2013 ).

Correspondence to:

Jean-Claude Loba-Mkole

Email:

lobamkolejeanclaude@

gmail.com

Postal address:

Private Bag X20, Hatfield

0028, Pretoria, South Africa

\section{Dates:}

Received: 29 Aug. 2013

Accepted: 01 Sept. 2013

Published: 06 Nov. 2013

How to cite this article: Loba-Mkole, J-C., 2013,

'Ethics of prayer and work in 1 and 2 Thessalonians', HTS Teologiese Studies/

Theological Studies 69(1),

Art. \#2056, 8 pages. http://

dx.doi.org/10.4102/hts.

v69i1.2056

\section{Copyright:}

(C) 2013. The Authors.

Licensee: AOSIS

OpenJournals. This work

is licensed under the

Creative Commons

Attribution License.

\section{Read online:}

Scan this QR
code with your
smart phone or
mobile device
to read online.

This article raises the question of the balance between prayer and work. This topic is discussed through an intercultural approach of Paul's recommendation about praying and working without ceasing (1 Th 1:9; 3:10). The main hypothesis postulates that constant prayer and

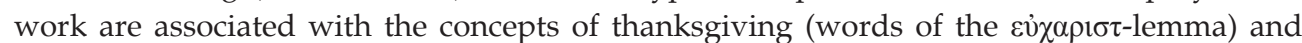
exemplarity. It is argued that Pauline recommendations about praying and working without ceasing prove to be supported not only by an original biblical culture, but also by a church culture as well as a currently emerging African culture.

\section{Introduction}

Praying to God is being in communion with God through acts of adoration, praise, blessing, thanksgiving or petition. Working is acting to maintain or improve one's knowledge and ability in given areas. Praying involves acting (i.e. active prayer) and acting implies praying (i.e. contemplative action). This article raises the question of the balance between prayer and work. The discussion of this topic is carried out through an intercultural approach of Paul's recommendations about praying and working without ceasing (1 Th $1: 9 ; 3: 10)$. The main hypothesis postulates that constant prayer and work are associated with the concepts of thanksgiving (words of the $\varepsilon \dot{v} \chi \alpha \rho \iota \tau$ lemma) and exemplarity. It is argued that Pauline recommendations about praying and working without ceasing prove to be supported not only by an original biblical culture, but also by a church culture as well as a currently emerging African culture. It assumes that giving thanks to God for whichever reason - or just because he is God ( $\operatorname{Rv} 11: 17)$ - is a form of prayer, whilst a work - that is, a good produced, received, being expected or something declined for a sound reason (cf. Rm 14:6) - can be the motif of a thanksgiving prayer. The words of the $\varepsilon v 0 \alpha \rho \imath \tau$-lemma appear over 50 times in the New Testament (Mt 15:36; 26:27; Mk 8:6, 7; 14:23; Lk 17:16; 18:11; 22:17, 19; Jn 6:11, 23; 11:41; Ac 24:3; 28:15; Rm 1:8; 7:25; 14:6 [2x]; 16:4; 1 Cor 1:4, 14; 10:30; 11:24; 14:16, 17, 18; 2 Cor 1:11; 4:15; 9:11, 12; Eph 1:16; 5:4, 20; Phlp 1:3; 4:6; Col 1:3, 12; 2:7; 3:17, 17; 4:2; 1 Th 1:2; $2: 13 ; 3: 9 ; 5: 18 ; 2$ Th 1:3; 2:13; 1 Tm 2:1; 4:3, 4; Phlm 1:4; Rv 4:9; 7:12; 11:17). They run from the gospel of Matthew to the book of Revelation, though they are lacking in Galatians, Hebrews, 2 Timothy, Titus and all the Catholic Epistles. Even if 1 Corinthians records more occurrences of the words of the $\varepsilon v \chi \alpha \rho ı \tau$-lemma (sevenfold), 1 Thessalonians remains the first historical basis for a case study on the thanksgiving concept of the New Testament canonical books, especially as Galatians - sometimes dated before 1 Thessalonians (see Bruce 1982:53-55; Hemer 1989:247-248) - is mute.

It is hoped that the intercultural exegesis which involves a constructive dialogue between original biblical cultures, church tradition cultures and contemporary cultures (cf. Loba-Mkole 2004a:3758, 2004b:79-115, 2005a:58-80, 2005b:291-326, 2007:39-68, 2008:253-266, 2010, 2012, 2013a, 2013b) will provide pertinent insights on prayer and work. Here culture refers to the totality of human experience in a given time and space, though this totality is accessible only through some channels, such as language and different kinds of knowledge. Besides, the term Africa or African refers to a geographical and multicultural entity; and for this study it also serves as a particular context, especially one that is represented by the views of some Bible translators and interpreters.

According to Van Binsbergen (2003:32-33), 'intercultural knowledge production is a form of mediation closely resembling to African reconciliation', as it is achieved not on the basis of demonstrable legal principles but on the invention of points of agreement. As for biblical intercultural exegesis - contrary to the broadly held assumptions of sola Scriptura - the biblical truth is to be sought in the point of agreement between the original cultures, church tradition cultures and present day cultures. Each set of cultures has a unique epistemological privilege for which it ought to be granted an active part in the interpretive process, be it the privilege of canonicity for the original biblical cultures, the privilege of elderliness for the church cultures of the past or the privilege of livingness for today's target cultures. Besides, it is worthwhile to keep in mind that an intercultural approach encompasses horizontal and vertical relations (Akper 2006:1-11; August 2006:12-18; Jonker 2006:19-28). Horizontal relations are experienced amongst 
the contemporary, neighbouring cultures whilst vertical relations are those that the current cultures establish with past cultures through remembering and with future cultures in terms of projections. Therefore, this article will undertake a dialogue on prayer and work experience, involving an African culture as point of departure and arrival, an Asian culture as an interface for horizontal interculturality, whilst the vertical interculturality will deal with a church culture of the past and the text of 1 and 2 Thessalonians as representing an original biblical culture. The points of resemblance, difference and agreement will be highlighted, so that current African cultures may knowingly decide the way forward. For this reason an intercultural approach starts preferably with main and parallel interpretations of a text in a target culture, including those of a neighbouring culture so that the culture concerned is treated as a key player in its own understanding of the text whilst taking into account a neighbour's views as well.

\section{Prayer and work in current African cultures}

Alongside inculturation, liberation and postcolonial criticism, the reconstruction paradigm constitutes a major interpretive tool operating on the African continent, especially amongst Christian theologians (cf. Dedji 2003; Mana 1993, 1994, 2000; Mugambi 1995, 2003; Villa-Vicencio 1992, 1999). How does this paradigm address the issue of unceasing commitment to prayer and work? I have dealt with the reconstruction topic in more detail elsewhere (Loba-Mkole 2009a), but without focusing on prayer and work. For the sake of the current study, it is sufficient to restate the positions of just two reconstruction protagonists, one francophone, Kä Mana, and one Anglophone, Jesse Mugambi. Mana (1993:117-8, 1994:216-22) posits four ethical and practical tasks of reconstruction theology: incarnation (immersion in the life of African societies), questioning oneself (contesting everything that alienates human dignity), liberation (freeing the imagination to overcome psychological illness, political inability, cultural dreariness, and economic anguish), and innovation (planting the seed of the kingdom of God on the political, economic, social, spiritual, and moral sites of the continent). Amongst these constructive task-areas, prayer and work can definitely fit anywhere, but most so within the innovation task in terms of a spiritual and economic seed of the reign of God in Africa.

Without any explicit contact with the work of Mana (1993, 1994), Mugambi $(1995,2003)$ treads on the same path of reconstruction as his francophone predecessor. He underscores that Africa needs to be (re)constructed at all levels (personal, cultural, ecclesiastical, political, economic, aesthetic, moral, and theological). Besides, all members of the community - whatever their gifts and talents - are invited to voluntarily place their expertise or labour where it is needed in the process of reconstruction for the good of the whole community (Mugambi 2003:74). Two points can be highlighted in Mugambi's reconstruction approach, namely the need of voluntary contribution and the explicit recognition of theology as one of the contributors. This recognition is significant for two reasons. Firstly, it comes from someone who is not primarily a theologian but a critic of religious literature; and secondly, it addresses the same concerns already expressed by a francophone theologian who is less known in Anglophone Africa. Therefore, a voluntary commitment to constant prayer and work would be cultivated as a specific contribution that both theologians and the people of God bring to the reconstruction process.

From an ecological perspective, as highlighted by Poucouta (2005), there are at the moment some serious challenges facing the middle-classes in Africa, namely the issues of a just wage, unemployment as well as the protection of the environment. The struggle for the environment seems to be on the frontline in holistic development strategies. But the engagement focussed on ecology takes into account all the places where life is destroyed, whether in politics and the economy or in the social, cultural, and ethical realm. In other words, the fight for the environment is at the same time a commitment to peace, justice, development, health, or simply life (Poucouta 2005:185). Again, this is an ecological deployment of the reconstruction paradigm, in which prayer and work will certainly contribute as catalysts for the betterment of life conditions.

What do African exegetes and Bible translators say about prayer and work, particularly in 1 Thessalonians? De Villiers (2006) points out that the eschatological perspective shapes the ethics proposed in the Thessalonian correspondence. 'Eschatology', he says, 'gives special urgency to responses to the Gospel and life in this world' (De Villiers 2006:343). He views the eschatological perspective as having 'the most mundane of ethical consequences' because 'believers need to act in such a way that they are found blameless in the day of the Lord (1 Th 5:23)' (De Villiers 2006:343). In other words, 'if the return of Christ is certain and even threatening, its delay means that no one should be idle, but work in quietness and earn their own living (2 Th 3:6-13)' (De Villiers 2006:343). Furthermore, De Villiers (2006:244-245) notes that 'eschatological expectations prevent any selfish inversion' and former individual pagans have become part of a new community, the family of God and are 'taken up in loving relationship to each other (1 Th 4:9).' This loving relationship exemplifies a holy lifestyle as response to God's call (De Villiers 2006:339), which certainly includes praying and working without idleness.

The African Bible (Zinkuratire et al. 2005) acknowledges that the relevance of 1 Thessalonians for Africa certainly includes the value of hard work and the advice of remaining calm and active whilst waiting for the second coming of Christ. However, the majority of people in Africa have challenges with entrepreneurship and expect the government to create better job conditions for them. Yet, through work the life-force of a whole community could be strengthened and enjoyed. Some African Christians are becoming more conscious that their work enhances their participation in God's work of creation and redemption. It is realised that, 
besides financial returns, work contributes in cultivating the spirit of solidarity and creativity with God and amongst fellow humans (Muyebe \& Muyebe 2002:175). Thus, human work symbolises a meeting place of immanence and transcendence, as it enhances people's dignity and liaises them with God the creator.

The African Bible commentary (Adeyemo 2006) emphasises that 'we need to be attuned to the changes that are taking place around us', since human beings and their cultures are not static but dynamic. This can be translated into a faithmotivated culture of work (cf. Nürnberger 1999:368), but specifically into a work culture whereby we produce more of what we consume and consume more of what we produce (Mazrui 1987). Indeed, the present culture is still dominated by a tendency of consuming what we do not produce and producing what we do not consume. This dilemma creates the so-called dependency syndrome amongst the majority of people whereby laziness and envy join hands to quench the spirit of creativity, productivity and freedom.

Schwartz (2007) provides a pastoral perspective. He tells a story about a local church that turned from dependency into a self-reliant community through prayer and work. After the majority of these church members had been retrenched from their jobs, they were faced with the option of appealing for assistance from the government or from international aid agencies. They opted rather for a different plan which, according to Schwartz (2007:278), consisted of a prayer meeting for the unemployed at 17:00 three days a week Monday, Wednesday and Friday. Schwartz (2007) continues:

It was not long until people became productive in their various areas of employment - particularly the fields in which their crops were grown ... They soon had so much produced that it could not all be used locally. They then began to pray about ways to get the produce to markets in the capital city many kilometres away. The church put legs to their own prayers, and businessmen with big trucks donated their services to carry the extra produce to the city. (pp. 278-279)

According to Schwartz (2007:231), this story was narrated as an illustration for 'overcoming unhealthy dependency in the Christian movement.' He gives ten reasons to support this move: a direct revelation from the Lord, a divine intervention to remove outside funds and personnel, sound teaching of those who sow the Gospel seed, sound teaching and practices promoted by committed and creative local church leaders, a one-sided plan initiated by missionaries, arbitrary cut of outside funding, widespread and genuine spiritual renewal, serious restructuring of the institutions inherited from the past, and a positive shift in attitude amongst local church members. This shift can be viewed, recommended and upheld as a newly emerging culture in Africa.

To sum up, interpreting prayer and work from the viewpoint of the reconstruction paradigm involves considering the two as integral parts of the innovation task in terms of spiritual and economic seeds of the reign of God in Africa (cf. Mana 1993, 1994, 2000); both ought to be cultivated as voluntary commitment by theologians and the people of faith (cf.
Mugambi 1995, 2003). Besides, it needs to be clearly stated that the reconstruction paradigm embraces environmental issues (cf. Poucouta 2005). Bible translators and exegetes, in their turn, recommend their readers to remain calm but active in view of their call to holiness and the coming of the Lord Jesus-Christ (cf. Zinkuratire et al. 2005; Adeyemo 2006; De Villiers 2006). A pastoral perspective has shown that prayer and work can overcome the dependency syndrome amongst Christians, relieve them from the unemployment plague and turn them into responsible members of God's reign on earth (cf. Schwartz 2007).

\section{Prayer and work in Asian cultures}

After the above overview on the prayer and work experience in Africa, it might be insightful to examine the prayer and work experience of one of the neighbouring continents. The experience of Asia, and one of its countries, Japan, in particular, offers a different and yet critically inspiring scenario in this regard. One of the major issues in Japan seems to be 'the total secularization and the economic focus of society. Neither in private nor in public do people care much about transcendence' (Yagi 2002b:75). This total secularisation is, paradoxically, an upshot of its philosophical and religious mindset, particularly that of Zen. In this system, 'the individuals are set in the absolute so that the individual and the absolute form a unity' (Yagi 2002a:33). The primordial fact is the 'unity of God and humanity': 'Not every human being is aware of this primordial fact. Only when one is awakened to it does a conscious religious life come about' (Yagi 2002a:36). This primordial fact is called 'God's primary contact with humanity', but the religious life evolved by awakening (enlightenment) to it is called 'God's secondary contact with humanity', 'individuum qua transindividuum', 'the self-ego', 'the true individual with no status', 'the person in whom the Buddha nature was activated' (Yagi 2002a:36, 41, 43). For Yagi (2002a:41, 43), one can compare this with what Paul calls 'the inner humanity' (cf. 2 Cor 4:16; see Betz 2000:315-341).

The Zen masters are usually 'transindividuals' who exemplify their status through diligent work as the following story shows:

When the Zen master Ungan visited his famous colleague Hyakujo, he asked the latter: 'Most honourable, who do you work for so diligently every day?' Hyakujo answered and said: 'There is the one who needs my work.' Ungan asked, 'Why do you not make him work himself?' Hyakujo answered: 'He alone cannot accomplish anything.' (Yagi 2002a:42)

The 'one' for whom the master worked is the transindividual, whereas the ' $\mathrm{I}$ ' that worked for the transindividual is the 'individual'. It has also been reported that once the famous master Hyakujo said: 'If one does not work on a day one should not eat that day' (cf. 2 Th 3:10; Yagi 2002a:42). This and other similar stories might account for the Japanese working culture that is built on perfection, discipline and teamwork, starting with oneself, that is, one's own multifaceted identity.

With regard to eschatological views, Zen masters are not worried about death or end of the world. In Yagi's terms 'for 
both Jesus and Paul, the eschaton is the image of the victory of God's reign' (Yagi 2002a:45). The difference between the two is that Paul never talked as if he were Christ, whereas Jesus did so. The great Zen masters act in a similar manner, knowing that their behaviour comes from the transindividual through the ego. In a conversation Shin-ichi Hisamatsu, a great Zen master, told Yagi: 'I do not die.' Yagi discovered only later in another conversation what Shin-ichi Hisamatsu had meant, namely: 'I am old. I can die any minute. When I am dead please continue the conversation with me who is in you' (Yagi 2002a:45).

The philosophy of Zen in Japan (Asia) encourages a human person to be active not only as an individual but also as a 'transindividual', combining both immanent and transcendent dimensions of work ('business' and 'faith'). Africa should therefore feel comforted by what is happening in a neighbouring continent where the transcendent and the immanent are not separated, even if the particular worldview about the transcendent may be different. If Asian or, more specifically, Japanese culture were to learn something from Paul, it would certainly be in the area of eschatological expectations. Christians from the Japanese culture should incorporate the awareness of Jesus' second coming on top of their calm expectation to be united to him on that day of the final victory of God's reign.

Arguably, Christians constitute the majority of the African population, which is not the case in Asia. Nevertheless, in terms of prayer and work both Asia and Africa share common views with regard to the unity between the transcendent and the immanent (faith and business). Moreover, Japanese philosophy encourages the qualities of teamwork, perfection and discipline. These can be borrowed by contemporary Africans to consolidate their efforts of rebuilding their continent, since their traditions equally emphasise the spirit of teamwork (or solidarity with the creator and all of creation). Nonetheless, the commitment to constant prayer and work can still be reinforced both in African and Asian cultures by relating it to an overall attitude of thanksgiving, as depicted in the Thessalonian correspondence.

\section{Thessalonians in a church culture}

This section is meant to show how the issue of work and prayer was interpreted within church traditions before Reformation times. Many church fathers and theologians dealt with this topic, but we will limit ourselves to the interpretations by the church father John Chrysostom (347-407) and the theologian Thomas Aquinas (1225-1274). The relevant thoughts from the former are displayed in the form of self-explanatory quotations that present Paul as a model for combining both ministry work and work for selfsustainability. Arguments from Thomas Aquinas are cited to point out a specific view about the Christian faith - that is, the faith that works through love.

John Chrysostom, for whom prayer is 'a state which endures by night and day' (Homily VI on prayer) comments on 1
Thessalonians 2:9-12 (Homily III) and on 2 Thessalonians 3:9-10 (Homily $V$ ) in the following terms:

The teacher ought to do nothing with a feeling of being burdened, that tends to the salvation of his disciples. For if the blessed Jacob was buffeted night and day in keeping his flocks, much more ought he, to whom the care of souls is entrusted, to endure all toils, though the work be laborious and mean, looking only to one thing, the salvation of his disciples, and the glory thence arising to God. See then, Paul, a man that was a Preacher, an Apostle of the world, and raised to so great honour, worked with his hands that he might not be burdensome to his disciples ... If Paul, not being under a necessity, and having a right to be idle, and having undertaken so great a work, did nevertheless work, and not merely work, but 'night and day,' so that he was able even to assist others, - much more ought others to do.

Thomas Aquinas is known to have commented on all Paul's letters, once during the years 1259-1265, and again from 1272-1273' (see Murphy 1966:viii). Nevertheless, commentaries by Thomas Aquinas himself run from Romans 1:1 to 1 Corinthians $7: 8$, the remaining pages having been supplied from notes taken by his disciples Peter of Tarentasia (cf. 1 Cor 7:10-9:27) and Reginald of Piperno (for the rest). Thomas Aquinas's own commentary on Galatians 5:6 testifies how Paul's statement on active faith (1 Th 1:3) reverberated in a different Pauline letter addressed to another early believing community (the Galatian community) and how it was understood by Thomas Aquinas himself, a leading philosopher and theologian of the Middle Ages.

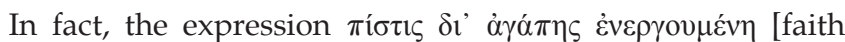
working through love] in Galatians 5:6 echoes the words of

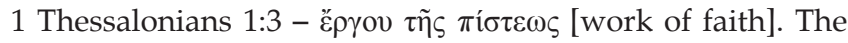
statement in Galatians 5:6 is found in a context where Paul is addressing the issue of work of the Law (circumcision) versus work of faith (life in Christ). Thomas Aquinas interprets this verse and says: 'In those who live in the faith of Christ, neither circumcision nor un-circumcision makes any difference; but faith, not unformed but the kind that works by charity' (see Murphy 2006). The angelic doctor goes on to stress this interpretation by quoting the epistle of James 2:26 ('faith without works is dead'). For him, faith is a knowledge of the Word of God (cf. Eph 3:17), which word is not perfectly possessed or perfectly known unless the love which it hopes for is possessed. Furthermore, Thomas Aquinas views Galatians 5:7 as stressing the point already made in Galatians 5:6 and he considers the obstacle that hindered the Galatians to obey the truth as the lack of the faith informed by charity (see Murphy 2006).

Does not the 'faith working through love' (Gl 5:6) and 'the work of faith' (1 Th 1:3) deal with distinct issues? Perhaps, but definitely not separate issues. The difference or distinction would have been more important had the apostle not talked about the fruit of love and even steadfastness of hope in the same verse and recommended the Thessalonians to be selfsupportive through their own income-generating activities (1 Th 4:9-12). Therefore, it is arguable that by 'work of faith' Paul meant both the efforts required of someone to live in Christ for reaching eternal life and the struggle to earn her or his living on earth. 


\section{Ethics of prayer and work in Thessalonians}

The Thessalonian Christians were mainly Greek-speaking non-Jews. In light of Acts 17, it can be argued that this community also consisted of a few Jews from the local synagogue, as many of them were 'behind the uprising of the townsfolk against Paul' (Van den Heever \& Scheffler 2001:152). Although Paul recommends self-reliance for his addressees, he received financial assistance at least twice during his stay in Thessalonica (cf. Phlp 4:16). This twofold assistance even suggests that Paul's sojourn in Thessalonica might have been longer than the three weeks mentioned in Acts 17:1-10 (Ellingworth 1997:1875). It has also been pointed out that 'the core of the Thessalonian community comprised hand-workers who shared Paul's trade' (Ascough 2000:135, 2004:526). There is a consensus amongst scholars that Paul's income-generating activity consisted of tent-making, which enabled him to be financially independent and to discharge freely his ministry of preaching the Gospel (1 Th 2:9; 1 Cor 9:12, 15, 18; cf. 2 Th 3:10-12; see Siemens 1997:124).

Combining praying and working seems to have been Paul's ethic (argument or principle of an ideal good) or his way of life (ethos), which he proposes and recommends to his Thessalonian audience. For Schnelle (1990:295-305, 2005:185), who views the motif of the Lord's coming as a basis for ethics within the macrostructure in 1 Thessalonians, Paul encourages his readers to live 'blamelessly' (1 Th 3:13; 5:23) and 'in holiness' (1 Th 3:13; 4:3, 4, 7; 5:23). This ethics is to be understood as a believer's response to God's call:

The beginning point of the Christian life, from which all else proceeds, is God's call, which results in the believer's response to the proclaimed gospel in faith, love, and hope (1:4-5; 2:12; 4:7-8). In 2:12 Paul already points to the call's relevance for ethics, to the causal connection between God's call and a worthy life. Love ( $\dot{\alpha} \gamma \dot{\alpha} \pi \eta)$ determines the content of the ethics of 1 Thessalonians (cf. 1:3; 5:8). (Schnelle 2005:186)

Fee (2009) is also of the opinion that the ultimate source of Paul's ethical instruction is a divine one:

Since Paul is about to zero in on a matter of morality that was not thought of as immoral in much of the Greco-Roman world, he concludes these introductory moments with the reminder that the ultimate source of his ethical instructions (commandments) is none than the Lord Jesus himself. (p. 141)

These ethical instructions deal basically with two moral flaws or sins, namely 'sexual immorality and a living style that is both idle and disruptive' (Fee 2009:141). It is interesting to see how Fee relates both sexual immorality and idleness to the content of Paul's prayer (1 Th 3:12-13) and the materialization of love amongst the Thessalonians. On the matter of idleness (cf. idlers as 'out of line') which is the opposite of a work attitude, Fee (2009) writes:

Paul now turns to the second item reported by Timothy to him and Silas that needs to be addressed in a correlative way. As with the preceding matter, this too was anticipated in his prayer in 3:12-13 that the 'Lord will cause your love for one another to abound.' This concern is now picked up in terms of their having 'been taught by God to love one another.' Although this matter is here addressed in a seemingly casual way, it is in fact one to which Paul will return specifically in the 'staccato imperatives' at the end of this letter (5:14); and since the present letter apparently failed to achieve its goal, he will pick it up even more vigorously in the next letter (2 Th 3:6-15). (p. 156)

The authenticity of 2 Thessalonians might be questioned, but the two volumes of the Thessalonian correspondence are together an integral part of the canon of the New Testament. On that ground, both of them have the authority to regulate issues pertaining to Christian faith and conduct, such as the ethics of prayer and work. After examining the two letters, Fee (2009) concludes about the idlers:

It is not 'idleness' per se that concerns Paul, but the unruly nature of their refusal to work and thus disrupting the shalom of the entire community that concerns him. Against that kind of 'idleness' there should be much legitimate concern in any community of faith. (p. 335)

In other words, Fee argues that living in holiness and blamelessly in view of the coming of the Lord is for the Thessalonian audience to be translated into mutual and universal love which excludes sexual immorality and idleness. Failure to abide by such ethics might generate unrest across social status boundaries, in the sense that sexual immorality and idleness can infect Jews and Gentiles, rich and poor, learned and unschooled, Christians and nonChristians.

\section{Thanksgiving prayer, work and exemplarity}

I have argued elsewhere (Loba-Mkole 2009b:7-8) that thanksgiving appears to be the main motif of 1 Thessalonians, running from the beginning to the end, whilst at the same time adorning this letter with the elegant style of inclusio (1 Th $1: 2 ; 2: 13 ; 3: 9 ; 5: 18)$. Besides, the thanksgiving motif in 1 Thessalonians goes hand in hand with that of exemplarity. How then do the motives of thanksgiving and exemplarity fit within the rhetorical structure of the letter?

The literary structure of 1 Thessalonians may be viewed as follows: prescription and greeting (1 Th 1:1), followed by thanksgiving and praise (1 Th 1:2-3:13) before embarking on exhortations and instructions (1 Th 4:1-5:28) which include Christian conduct (1 Th 4:1-12), the coming of Christ (1 Th 4:13-5:11), as well as last exhortations and greetings (1 Th 5:12-28). Other slightly different structures have been proposed by Jewett (1986), Hughes (1990), Porter (1997) and Van Sebroeck (2004). They display key sections such as an exordium (1 Th 1:1-10), a narratio (1 Th 2:1-12), a vituperatio (1 Th 2:13-3:13), a probatio (1 Th 4:1-12), an inclusio (1 Th 4:13$5: 11$ ), paraenesis (1 Th 5:12-24) and a peroratio (1 Th 5:25-28).

There are various reasons for thanksgiving in 1 Thessalonians. Paul and his companions (Silvanus and Timothy) declare that

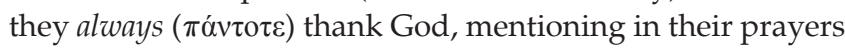
the addressees of whom they continuously ( $\dot{\alpha} \delta \alpha \lambda \varepsilon i \pi \tau \omega \varsigma)$

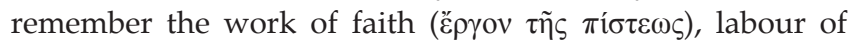

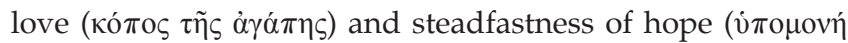




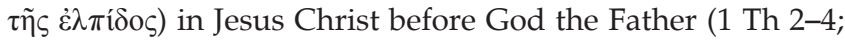
cf. 1 Cor 13:13). From the onset, this prayer of thanksgiving is directly related to the work done not only by the human addressees in terms of their active faith, effective love and staunch hope, but also for the work accomplished by the One and Triune God. Indeed, God the Father loved and chose the Thessalonians, whilst the Holy Spirit empowered the preaching of the Gospel through which Jesus Christ, the Son, arrived amongst them and triggered their faith, love and hope. Furthermore, the thanksgiving prayer obviously includes the prayer and the work or ministry of gospel preaching that the authors (Paul, Silvanus and Timothy) carried out amongst the Thessalonians through the power of the Holy Spirit. If that is the case, the prayer of thanksgiving in the context of 1 Thessalonians is linked not only to work but also to exemplarity. From the beginning of 1 Thessalonians, the authors are straightforwardly presented as exemplar(s) in matters of prayer and work $(1: 2,6)$. This is corroborated by the autobiographical section (2:1-12) and by different reasons of thanksgiving and various exhortations (2:13-5:28).

Prompted by Malherbe (1970:203-217), several studies have discussed whether the nature of the rhetoric at hand is forensic, deliberative, epideictic or paraenetic (Walton 1995:229-250). Some scholars think that Paul is using a forensic rhetoric to defend himself against his opponents, especially in the section of 1 Thessalonians 2:1-12 (e.g. Schmithals 1972:177-178; Johanson 1987:58). Others regard the rhetoric of 1 Thessalonians as deliberative (Kennedy 1984; Johanson 1987:166) or as epideictic, since Paul would want to consolidate an existing relationship (Jewett 1986:7172; Hughes 1990:106) or because he emphasises praise (1 Th 2:1-12) and blame (1 Th 2:14-16; cf. Lyons 1985:220).

Without repeating each argument about the nature of Pauline rhetoric in 1 Thessalonians, it is sufficient to refresh the mind with a summary of the study by Lions, as Walton (1995) recalls it:

He goes on to discuss a number of aspects of Paul's exemplary ethos which become explicit in his paraenesis, namely his encouragement or exhortation (2:3, 11-12; 4:1, 18; 5:11); his holy and blameless moral conduct $(2: 3,9-12 ; 4: 1-7 ; 5: 22-23)$; his sense of responsibility to please God $(2: 4,15 ; 4: 1)$; his brotherly love and constant friendship, both whilst with and whilst parted from the Thessalonian Christians (2:5-8, 17-18; 3:6, 10, 12; 4:9-12; 5:15); his manual labour and self-support (2:8-9; 4:9-12; 5:12-14); his constant prayers of thanksgiving (1:2; $2: 13 ; 3: 10 ; 5: 17-18)$; his joy in the midst of affliction (1:6; 3:9-10; 5:16-18); and his eschatological hope (1:10; 2:19-20; 3:13; 4:13-5:11). (p. 247)

This is a fair indication that in 1 Thessalonians the thanksgiving prayer is closely related to work and exemplarity. It is no wonder that different critics emphasise one aspect of the rhetoric at work in this letter: forensic, deliberative, epideictic or paraenetic. However, it is not impossible for a single letter to combine different types of rhetoric even if one or some might be more salient than others. Malherbe (1983:240-241) argued for paraenetic rhetoric as the most dominant one in Thessalonians, given that 'a major part of ancient parænesis was the offering of a model to be imitated.'
Indeed, 2 Thessalonians 3:6-16 is more eloquent than any other comment and is self-explanatory:

Now we command you, brethren, in the name of our Lord Jesus Christ, that you keep away from any brother who is living in idleness and not in accord with the tradition that you received from us. For you yourselves know how you ought to imitate us; we were not idle when we were with you, we did not eat any one's bread without paying, but with toil and labor we worked night and day, that we might not burden any of you. It was not because we have not that right, but to give you in our conduct an example to imitate. For even when we were with you, we gave you this command: If anyone will not work, let him not eat. For we hear that some of you are living in idleness, mere busybodies, not doing any work. Now such persons we command and exhort in the Lord Jesus Christ to do their work in quietness and to earn their own living. Brethren, do not be weary in well-doing. If anyone refuses to obey what we say in this letter, note that man, and have nothing to do with him, that he may be ashamed. Do not look on him as an enemy, but warn him as a brother. Now may the Lord of peace himself give you peace at all times in all ways. The Lord be with you all. (Revised Standard Version)

Siemens (1997) rightly calls upon this passage to support his case for a biblical work ethic:

Did you ever notice how much Paul says in his short letters about work? (2 Thess. 3:6-15). Converts were to earn their living quietly. If they did not work, they should not eat. Without a strong biblical work ethic there could not be strong Christians. (p. 124)

In view of Malherbe (2000:viii-ix), both 1 and 2 Thessalonians display the literary or rhetorical structures in which thanksgiving and exhortation elements are paramount. $\mathrm{He}$ subdivides 1 Thessalonians in four sections: address ( 1 Th 1:1), autobiography (1 Th 1:2-3:13), exhortation (1 Th 4:1-5:22) and conclusion (1 Th 5:23-28). He structures 2 Thessalonians in five sections: address (2 Th 1:1-2), thanksgiving and exhortation (2 Th 1:3-2:12), thanksgiving and exhortation (2 Th 2:13-3:5), commands (2 Th 3:6-15) and conclusion (2 Th 3:16-18). All these sections are built up around thanksgiving and exhortation motifs, which strongly betray the purpose of exemplarity, especially when they also include a specific section on autobiography. Whether both letters were written by the same author(s) or not, their composition style exhibits the same features.

From the perspective of social identification rhetoric, exemplars are meant to construct a social identity of their followers through the rhetoric that consolidates the ingroup cohesion, collective memory, as well as generating stereotypes for the outsiders (Hogg \& Abrams 1988; Tajfel \& Turner 2001). Expressions such as 'we thank God for all of you', 'we pray for you', 'we mention you in our prayers', 'we remember you', 'we exhort you', 'imitator-words' as well as many ethical indicatives and imperatives (cf. Du Toit 2007; Tsui 2013:314), contribute to confirm the role of the exemplars and to strengthen the group identity. The author(s) of 1 and 2 Thessalonians have been living up their role models vis-à-vis their group-members for whom they are instilling the ethics of constant thanksgiving prayer and work, as Malherbe (2012) asserts with regard to the leading exemplar: 
Paul begins the letter with a three-chapter account of his relationship with his recent converts. The purpose of this narrative is to strengthen the bond between them to form the basis for the moral direction that will follow in the final two chapters of the letter, which are usually described as paraenetic. The narrative in fact serves a paraenetic function. Paul uses a style adopted from the moral philosophers of his day in this autobiographical narrative, which culminates in an expression of joy that his converts still hold him as the moral example to whom they look for guidance. (p. 207)

In a nutshell, the letters to the Thessalonians are structured around the thanksgiving motif with a strong flavour of paraenetic rhetoric. These letters present Paul and his companions as models to imitate with regard to constant prayer and work.

\section{Conclusion}

In a Christian community, prayer and work ought to be closely related to the life of faith. According to the Pauline correspondence to the Thessalonians, prayer and work are the only items that are to be performed unceasingly in the life of Christians (1 Th 2:9; 3:10; see also 2 Th 3:6-16). Prayer or work of faith here refers to any faith-motivated activity that is informed by love. Nevertheless, the experience of prayer and work seems to be culturally determined. This may account for the similarity and difference between the experience of prayer and work in the contemporary communities, church traditions and original biblical cultures. The similarity between the three cultures can be illustrated by the importance that is allocated to work in current cultures (cf. Africa, Asia), in church tradition (cf. John Chrysostom, Thomas Aquinas) and in the Thessalonian correspondence.

The differences amongst the sets of cultures explored here relate to the view that work and prayer go hand in hand in the Thessalonian correspondence and in the church tradition represented by John Chrysostom and Thomas Aquinas, whilst in current Africa prayer and work do not seem to be well coordinated as many rely on government jobs; the Asian culture tends to focus on work more than prayer. Fortunately, a new culture that promotes the balance between prayer and work is emerging in Africa. Moreover, prayer in Asian culture might be seen as part of the Zen immanent transcendence, where the commitment to perform a work perfectly is synonymous with prayer. Another difference resides in the fact that the second coming of Christ is not a big deal for an Asian Christian because of Asia's philosophy of immanent transcendence, whilst some Africans can act like the Thessalonian busybodies who were waiting for Jesus to come the next day. As a result, those busybodies could not concentrate on any rewarding work. Yet, they were looking for food to eat without paying, which is still common in Africa. In terms of epistemological value, the Pauline recommendation about praying and working without ceasing is in consonance with an African proverb, 'If you don't work you shan't eat', as well as with Jesus' saying in John 5:17, 'My Father is working still, and I am working.' The tradition of ora et labora [pray and work], laid down by Saint Benedict of Nursia (480-543), is well known in church history. The most important ethical lesson to learn from the Thessalonian correspondence pertains to the exemplarity of Paul and his companions in relation to constant prayer and work.

\section{Acknowledgements Competing interests}

The author declares that he has no financial or personal relationship(s) which may have inappropriately influenced him in writing this article.

\section{References}

Adeyemo, T. (ed.), 2006, Africa Bible commentary: A one-volume commentary written by 70 African scholars, WordAlive, Nairobi.

Akper, G.I., 2006, 'From multiculturality to interculturality? Locating the ongoing African agency discourse in the debate', Scriptura 91(1), 1-11.

August, K.K., 2006, 'The nature of interculturality in development: A theological perspective of relationality', Scriptura 91(1), 12-18.

Ascough, R., 2000, 'The Thessalonian Christian community as a professional voluntary association', Journal of Biblical Literature 119(2), 311-328. http://dx.doi. org/10.2307/3268489

Ascough, R., 2004, 'A question of death: Paul's community-building language in 1 Thessalonians 4:13-18', Journal of Biblical Literature 123(2), 509-530. http:// dx.doi.org/10.2307/3268045

Betz, D.H., 2000, 'The concept of the "inner human being" in Paul's anthropology', New Testament Studies 46(3), 315-341.

Bruce, F.F., 1982, The Epistle of Paul to the Galatians: A commentary on the Greek text, Paternoster, Exeter.

De Villiers, P.G.R., 2006, 'A life worthy of God': Identity and ethics in the Thessalonian correspondence, in J. van der Watt (ed.), Identity, ethics, and ethos in the New Testament, pp. 335-356, de Gruyter, Berlin.

Dietrich, W. \& Luz, U. (eds.), 2002, The Bible in a world context: An experiment in contextual hermeneutics, Eerdmans, Grand Rapids.

Dedji, V., 2003, Reconstruction and renewal in African theology, Acton, Nairobi.

Du Toit, A., 2007, Focusing on Paul : Persuasdion and theological design in Romans and Galatians, ed. C. Breytenbach \& D.S. du Toit de Gruyter, Berlin.

Ellingworth, P. (ed.), 1997, Good News Study Bible, United Bible Societies, Reading.

Fee, D.G., 2009, The First and Second Letters to the Thessalonians, Eerdmans, Grand Rapids.

Gillaerts, P. (ed.), 2004, Boanerges: Beschouwingen over Bijbel (vertaling) en retorica, Acco, Leuven, Voorburg.

Hemer, J.C. 1989, The book of Acts in the setting of Hellenistic history, Mohr, Tübingen. PMid:2760058

Hogg, A.M. \& Abrams, D., 1988, Social identifications: A social psychology of intergroup relations and group processes, Routledge, London.

Homily III, 1 Thessalonians ii. 9-12, in Christian Classics Ethereal Library, viewed n.d., from http://www.ccel.org/ccel/schaff/npnf113.iv.v.iii.html

Hughes, F.W., 1990, 'The rhetoric of 1 Thessalonians', in R.F. Collins (ed.), The Thessalonian correspondence, pp. 97-107, Leuven University Press, Leuven.

Jewett, R., 1986, The Thessalonian correspondence: Pauline rhetoric and millenary piety, Fortress Press, Philadelphia.

Jonker, L., 2006, 'From multiculturality to interculturality: Can intercultural biblical hermeneutics be of any assistance?' Scriptura 91(1), 19-28.

Johanson, B.C., 1987, To all the brethren: A text-linguistic and rhetorical approach to 1 Thessalonians, Almqvist \& Wiksell International, Uppsala.

Mana, K., 1993, Théologie africaine pour temps de crise. Christianisme et reconstruction de l'Afrique, Karthala, Paris.

Mana, K., 1994, Christ d'Afrique. Enjeux éthiques de la foi africaine en Jésus-Christ, Karthala, Paris.

Mana, K., 2000, La nouvelle évangelisation en Afrique, Karthala, Paris.

Kennedy, A.G, 1984, New Testament interpretation through rhetorical criticism, University of North Carolina Press, Chapel Hill.

Lyons, G., 1985, Pauline autobiography: Towards a new understanding, Scholars Press, Atlanta.

Loba-Mkole, J-C., 2004a, 'Bible translation and intercultural hermeneutics', in E. Wendland \& J-C. Loba-Mkole, Biblical texts and African audiences, pp. 37-58, Acton, Nairobi.

Loba-Mkole, J-C., 2004b, 'Exegesis and translation of Mark for an audio-visual culture', Journal of Biblical Text Research 24, 76-115.

Loba-Mkole, J-C., 2005a, 'Notes on the Holy Spirit for a Kongo Study Bible', in J-C. Loba-Mkole \& E. Wendland (eds.), Interacting with Scriptures in Africa, pp. 56-80, Acton, Nairobi. 
Loba-Mkole, J-C., 2005b, 'The social setting of Jesus' exaltation in Luke-Acts (Lk 22:29 and Ac 7:56)', HTS Teologiese Studies/Theological Studies 61(1/2), 291326. $\mathrm{http}: / / \mathrm{dx}$.doi.org/10.4102/hts.v61i1/2.441

Loba-Mkole, J-C., 2007, 'From inculturation theology to intercultural exegesis', in A Kabasele-Mukenge, J-C. Loba-Mkole \& D. Aroga Bessong (eds.), Cultural readings of the Bible in Africa', pp. 39-68, Clé, Yaoundé.

Loba-Mkole, J-C., 2008, 'History and theory of Scripture translations', HTS Teologiese Studies/Theological Studies 64(1), 253-266. http://dx.doi.org/10.4102/hts. v64i1.20

Loba-Mkole, J-C., 2009a, 'Bible translation and reconstruction hermeneutics', Acto Patristica et Byzantina 20, 28-44.

Loba-Mkole, J-C., 2009b, 'Prayer and work in 1 Thessalonians: Paul's struggle for selfreliance', in CUEA, Celebrating the Jubilee Year of Saint Paul: Apostle, Missionary, and Martyr, pp. 257-276, CUEA Press, Nairobi.

Loba-Mkole, J-C., 2010, 'The New Testament and intercultural exegesis in Africa', in P. Foster (ed.), New Testament studies, pp. 115-132, SAGE, London.

Loba-Mkole, J-C., 2011, 'Paul and Africa?', HTS Teologiese Studies/Theological Studies 67(1), Art. \#888, 11 pages. http://dx.doi.org/10.4102/hts.v67i1.888

Loba-Mkole, J-C., 2012, Triple Heritage: Gospels in intercultural mediations, Worldlive, Nairobi.

Loba-Mkole, J-C., 2013a (forthcoming), 'Interculturality in peace building (Rm 14:19)' in G.J. Steyn (ed.), Reflecting on Romans. Essays in honour of Andrie du Toit's 80th birthday, Leuven University Press, Leuven.

Loba-Mkole, J-C., 2013b (forthcoming), 'Intercultural criticism of New Testament translations', Translation.

Malherbe, A.J., 1970, "'Gentle as a nurse": The Cynic background to I Thess ii', Novum Testamentum 12, 203-217

Malherbe, A.J., 1983, 'Exhortation in First Thessalonians', Novum Testamentum 25, 238-256. http://dx.doi.org/10.1163/156853683X00041

Malherbe, A.J., 2000, The letters to the Thessalonians: A new translation with introduction and commentary, Doubleday, New York.

Malherbe, A.J., 2012, 'Ethics in context: The Thessalonians and their neighbours', HTS Teologiese Studies/Theological Studies 68(1), Art. \#1214, 10 pages. http://dx.doi. org/10.4102/hts.v68i1.1214

Mazrui, A.A., 1987, The Africans: A triple heritage, Little Brown and Company, London.

Mugambi, J.N.K., 1995, From liberation to reconstruction: African Christian theology after the Cold War, East African Educational Publisher, Nairobi.

Mugambi, J.N.K., 2003, Christian theology and social reconstruction, Acton, Nairobi.

Murphy, T.A.R. (ed.), 1966, Thomas Aquinas: Commentary on Saint Paul's Epistle to the Galatians, transl. F.R. Larcher, Magi Books, Albany. (Aquinas Scripture Series 1)

Muyebe, S. \& Muyebe, A., 2002, The African Bishops on human rights: A resource book, Paulines Publications Africa, Nairobi.
Nürnberger, K., 1999, Prosperity, poverty and pollution: Managing the approaching crisis, Cluster Publications, Pietermaritzburg.

Porter, E.S., 1977, 'Paul of Tarsus and his letters', in S. Porter (ed.), Handbook of classical rhetoric in the Hellenistic period 330 B.C -A.D 400, pp. 533-585, Brill, Leiden.

Poucouta, P., 2005, 'La théologie africaine au défi de l'écologie', Revue Africaine de Théologie 56, 171-186.

Schnelle, U. 1990, 'Die Ethik des 1 Thessalonikerbriefes', in R.E. Collins and N. Baumert (eds.), The Thessalonian Correspondance, pp. 295-305, Leuven University Press, Leuven.

Schnelle, U., 2005, Apostle Paul: His life and theology, transl. E. Boring, Baker Academic, Grand Rapids.

Sebroeck, F. van, 2004, "'Niet alleen door onze woorden": Retoriek in 1 Tessalonicenzen?', in P. Gillaerts (ed.), Boanerges: Beschouwingen over Bijbel (vertaling) en retorica, pp. 87-101, Acco, Leuven/ Voorburg.

Siemens, E.R., 1997, 'The vital role of tentmaking in Paul's mission strategy', International Journal of Frontier Missions 14(3), 121-129.

Schmithals, W., 1972, Paul and the gnostics, Abingdon Press, Nashville.

Schwartz, J.G., 2007, When charity destroys dignity: Overcoming unhealthy dependency in the Christian movement, World Mission Associates, Lancaster.

Tajfel, H. \& Turner, J.C., 2001, 'An integrative theory of intergroup conflict', in D. Abrams \& M.A. Hogg (eds.), Intergroup relations: Essential readings, pp. 94-109, Psychology Press, Hove.

Tsui, T.K., 2013, 'Reconsidering Pauline juxtaposition of indicative and imperative (Romans 6:1-14) in light of Pauline apocalypticism', Catholic Biblical Quarterly 75(2), 297-314.

Van Binsbergen, W., 2003, Intercultural encounters: African and anthropological lessons towards a philosophy of interculturality, LIT Verlag, Münster.

Van den Heever, G.A. \& Scheffler, E.H., 2001, From Jesus Christ to Christianity: Early Christian literature in context, Unisa Press, Pretoria. PMid:11885771

Villa-Vicencio, C., 1992, Theology of reconstruction, Cambridge University Press, Cambridge. http://dx.doi.org/10.1017/CBO9780511607592

Villa-Vicencio, C., 1999, 'Liberation and reconstruction: The unfinished agenda', in C. Rowland (ed.), The Cambridge companion to Liberation Theology, pp. 153-176, Cambridge University Press, Cambridge. http://dx.doi.org/10.1017/ CCOL0521461448.008

Walton, S., 1995, 'What has Aristotle to do with Paul? Rhetorical criticism and 1 Thessalonians', Tyndale Bulletin 46(2), 229-250.

Yagi, S., 2002a, 'Ego and self in the New Testament and in Zen', in W. Dietrich \& U. Luz (eds.), The Bible in a world context, pp. 33-49, Eerdmans, Grand Rapids. PMid:12214161

Yagi, S., 2002b, 'Mary and Maya', in W. Dietrich \& U. Luz (eds.), The Bible in a world context, pp. 71-75, Eerdmans, Grand Rapids. PMid:12089130, PMCid:PMC1751140

Zinkuratire, V. et al. (eds.), 2005, The African Bible: Biblical text of the New American Bible, Paulines Publications Africa, Nairobi. 